Nevada

Environmental

Restoration

Project

Post-Closure Inspection Report for Corrective Action Unit 90: Area 2 Bitcutter Containment, Nevada Test Site, Nevada

For the Period

July 2007-June 2008

Controlled Copy No.:

Revision: 0

September 2008

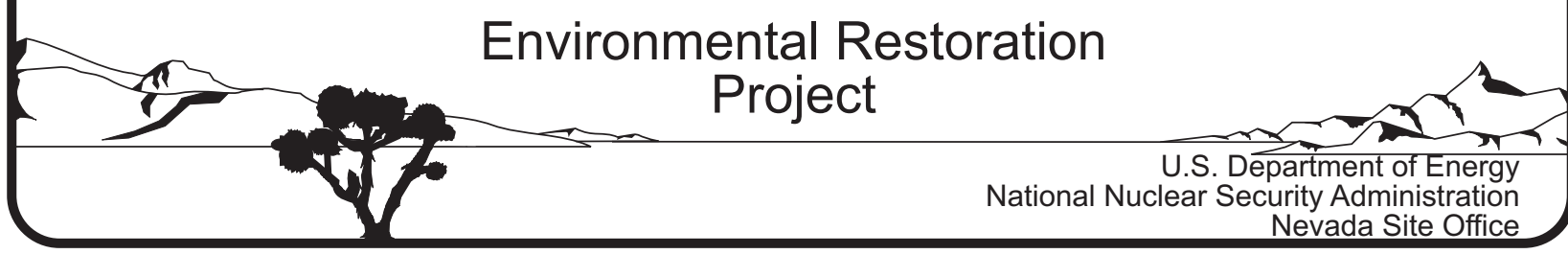




\section{DISCLAIMER}

Reference herein to any specific commercial product, process, or service by trade name, trademark, manufacturer, or otherwise, does not necessarily constitute or imply its endorsement, recommendation, or favoring by the United States Government or any agency thereof.

This report has been reproduced directly from the best available copy.

Available for sale to the public from:

U.S. Department of Commerce

National Technical Information Service

5285 Port Royal Road

Springfield, VA 22161-0002

Telephone: (800) 553-6847

Fax: (703) 605-6900

Email: orders@ntis.gov

Online ordering: http://www.ntis.gov/ordering.htm

Available electronically at http://www.osti.gov/bridge.

Available for a processing fee to the U.S. Department of Energy and its contractors, in paper, from:

U.S. Department of Energy

Office of Scientific and Technical Information

P.O. Box 62

Oak Ridge, TN 37831-0062

Telephone: (865) 576-8401

Fax: (865) 576-5728

E-mail: reports@adonis.osti.gov 


\title{
POST-CLOSURE INSPECTION REPORT FOR CORRECTIVE ACTION UNIT 90: AREA 2 BITCUTTER CONTAINMENT, NEVADA TEST SITE, NEVADA
}

\author{
FOR THE PERIOD \\ JULY 2007-JUNE 2008
}

\author{
U.S. Department of Energy \\ National Nuclear Security Administration \\ Nevada Site Office \\ Las Vegas, Nevada
}

Controlled Copy No.:

Revision: 0

September 2008 
THIS PAGE INTENTIONALLY LEFT BLANK 


\title{
POST-CLOSURE INSPECTION REPORT FOR CORRECTIVE ACTION UNIT 90: AREA 2 BITCUTTER CONTAINMENT, NEVADA TEST SITE, NEVADA
}

\author{
FOR THE PERIOD \\ JULY 2007-JUNE 2008
}

Approved By:

/s/ Kevin Cabble

\section{Kevin J. Cabble}

Federal Sub-Project Director

Industrial Sites Sub-Project

\footnotetext{
Approved By: /s/ Robert Boehlecke

Robert F. Boehlecke

Federal Project Director

Environmental Restoration Project
}

Date: $9-4-08$ 
THIS PAGE INTENTIONALLY LEFT BLANK 
Date: September 2008

\section{TABLE OF CONTENTS}

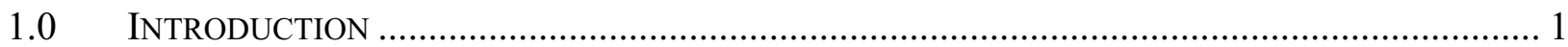

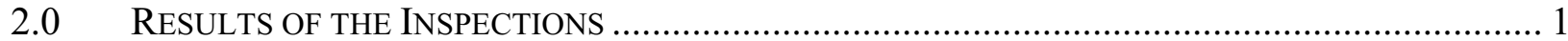

CONCLUSIONS AND RECOMMENDATIONS.................................................................. 1

LIBRARY DISTRIBUTION LIST

\section{APPENDICES}

ApPendix A. Post-Closure Inspection Checklists

APPENDIX B. FIELD Notes

APPENDIX C. INSPECTION PHOTOGRAPHS 
CAU 90 Post-Closure Report

Revision: 0

Date: September 2008

\section{THIS PAGE INTENTIONALLY LEFT BLANK}




\subsection{INTRODUCTION}

Corrective Action Unit (CAU) 90, Area 2 Bitcutter Containment, is identified in the Federal Facility Agreement and Consent Order of 1996, as amended February 2008. The post-closure requirements for CAU 90 are described in Section VII.B.8.b of the Nevada Test Site Resource Conservation and Recovery Act Permit for a Hazardous Waste Management Facility Number NEV HW0021, dated November 2005.

Post-closure activities consist of the following:

- Semiannual inspections of the site using inspection checklists

- Photographic documentation

- Field note documentation

- Preparation and submittal of an annual Post-Closure Inspection Report

This annual report covers the period of July 2007 to June 2008 and consists of a summary of the results of the inspections, copies of the inspection checklists and field notes, maintenance and repair records (if any), photographs, and conclusions and recommendations. The inspection checklists are provided in Appendix A, a copy of the field notes is provided in Appendix B, and copies of photographs taken during the inspections are provided in Appendix C.

\subsection{RESULTS OF THE INSPECTIONS}

The semiannual inspections for CAU 90 were performed on December 18, 2007, and June 17, 2008.

The December inspection indicated continued integrity of the unit. Only one animal burrow was observed near a survey marker with no impact to the cover. The fencing and signs were in excellent condition. No repairs or maintenance were recommended.

Vegetation that required removal was discovered at other CAUs during quarterly inspections in March 2008. Based on findings in other years, it was assumed that vegetative growth requiring removal would likely be present at CAU 90 also. Vegetation removal was completed as a best management practice on May 13, 2008.

The June inspection also indicated continued integrity of the waste unit cover. No animal burrows were noted on the cover. Some light vegetation was present on both covers and will be removed within 60 days of the inspection. Fencing and signs were in excellent condition. The use restriction signs will be updated to current guidance standards as a best management practice with concurrence by the Nevada Division of Environmental Protection; however, this update is not required to be completed within the regulatory compliance period.

\subsection{CONCLUSIONS AND RECOMMENDATIONS}

All inspections at CAU 90 indicated continued integrity of the unit. It is recommended to continue inspections as scheduled. Vegetation removal is necessary within 60 days of the June 17, 2008, inspection. 
CAU 90 Post-Closure Report

Revision: 0

Date: September 2008

\section{THIS PAGE INTENTIONALLY LEFT BLANK}


CAU 90 Post-Closure Report

Revision: 0

Date: September 2008

\section{APPENDIX A}

\section{Post-Closure InsPection Checklists}


CAU 90 Post-Closure Report

Revision: 0

Date: September 2008

THIS PAGE INTENTIONALLY LEFT BLANK 


\section{POST-CLOSURE INSPECTION CHECKLIST}

\section{CAU 90: AREA 2 BITCUTTER CONTAINMENT - CAS 02-20-01: Bitcutter/PS Inj. Wells (3) (RCRA)}

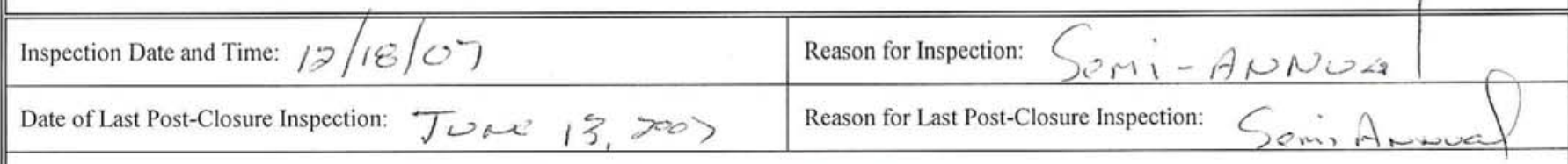

Responsible Entity: NSTec Environmental Restoration, Nevada Test Site, Mercury, Nevada

Responsible Facility Owner: Jeffrey L. Smith, Deputy Manager, Environmental Restoration

Chief Inspector:

\section{A. GENERAL INSTRUCTIONS}

1. All checklist items must be completed and detailed comments made to document the results of the site inspection. The completed checklist is part of the field record of the inspection. Additional pages should be used as necessary to ensure that a complete record is made. Attach the additional pages and number all pages upon completion of the inspection.

2. Any checklist line item marked by an inspector in a SHADED BOX must be fully explained or an appropriate reference to previous reports provided. The purpose of this requirement is to provide a written explanation of inspector observations and the inspector's rationale for conclusions and recommendations. Explanations are to be placed on additional attachments and cross-referenced appropriately. Explanations, in addition to narrative, will take the form of sketches, measurements, and annotated site maps.

3. The site inspection is a walking inspection of the entire site including the perimeter and sufficient transects to be able to inspect the entire surface and all features specifically described in this checklist.

4. A standard set of color photographs is required. In addition, all anomalous features or new features (such as changes in adjacent area land use) are to be photographed. A photograph log entry will be made for each photograph taken.

5. Field notes taken to assist in completion of this checklist will become part of the inspection record. No form is specified for field notes; however, they must be legible and in sufficient detail to enable review by succeeding inspectors and the responsible agency.

6. This unit will be inspected semi-annually with formal reporting to the Nevada Division of Environmental Protection to be done annually. The annual report will include an executive summary, this inspection checklist with field notes and photograph log attached, and recommendations and conclusions.

\begin{tabular}{|c|c|c|c|c|}
\hline B. PREPARATION (To be competed prior to site visit) & YES & NO & \multicolumn{2}{|c|}{ EXPLANATION (required if shaded box is checked) } \\
\hline \multicolumn{5}{|l|}{ 1. Has the Post-Closure Permit been reviewed? } \\
\hline \multicolumn{5}{|l|}{ 2. Has the Post-Closure Permit application been reviewed? } \\
\hline 3. Has the Post-Closure Plan been reviewed? & & & & $\cdot$ \\
\hline \multicolumn{5}{|l|}{ 5. Have the previous inspection reports been reviewed? } \\
\hline a. Were anomalies or trends detected on previous inspections? & & $\sim$ & \multicolumn{2}{|r|}{. } \\
\hline \multicolumn{5}{|l|}{ b. Was maintenance performed? } \\
\hline $\begin{array}{l}\text { a. If so, has site repair resulted in a change from as-built } \\
\text { conditions? }\end{array}$ & & & \multicolumn{2}{|l|}{ NA } \\
\hline $\begin{array}{l}\text { b. If yes (to } 6 \mathrm{a} \text { ), are revised as-built plans available that reflect } \\
\text { repair changes? }\end{array}$ & & & NA & \\
\hline
\end{tabular}




\section{POST-CLOSURE INSPECTION CHECKLIST}

\section{CAU 90: AREA 2 BITCUTTER CONTAINMENT - CAS 02-20-01: Bitcutter/PS Inj. Wells (3) (RCRA)}

\section{SITE INSPECTION PREPARATION}

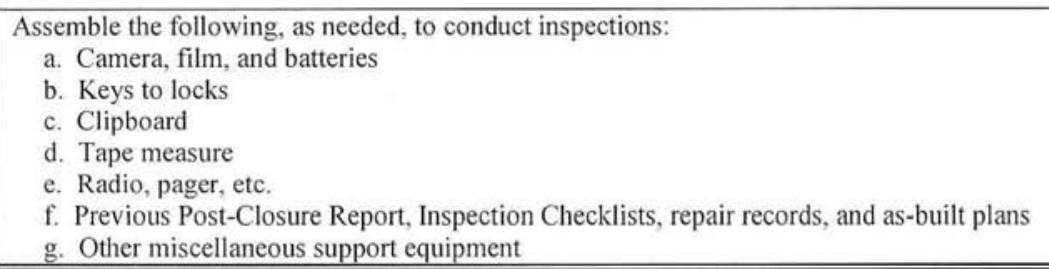

\section{SITE INSPECTION}

1. Adjacent off-site features:

a. Are there any new activities or features in the vicinity that could potentially affect the site (e.g., activities that change the flow of surface water or are encroaching the unit)?

2. Fences, gates, and signs (East Fenced Enclosure):

a. Is there damage to or a break in the fence?

b. Have any fenceposts been damaged or their anchoring weakened?

c. Is the gate intact and functional?

d. Does the gate show evidence of tampering or damage?

e. Was the gate locked?

f. Are any of the use restriction signs damaged or missing?

g. Are all use restriction signs legible?

h. How many use restriction signs need to be replaced?

i. Other?

3. Waste unit cover (East Fenced Enclosure):
a. Is there evidence of settling?
b. Is there evidence of cracking?
c. Is there evidence of erosion (wind or water)?
d. Is there evidence of human intrusion onto the cover?
e. Is there evidence of large animal intrusion onto the cover?
f. Is there evidence of animal burrowing?
g. Is vegetation growing on the cover?
h. Other (including trash, debris, etc within fenced area)?

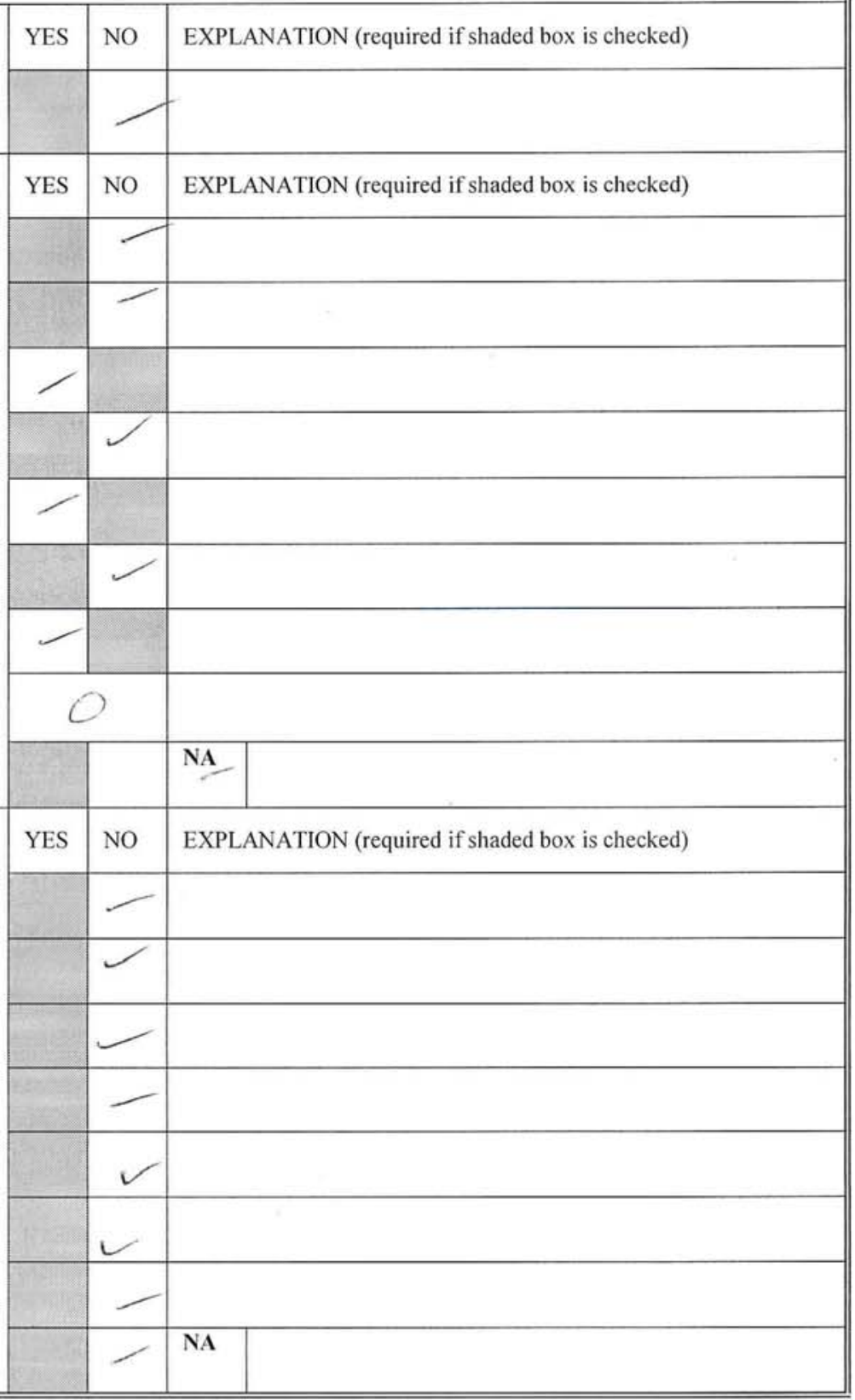




\section{POST-CLOSURE INSPECTION CHECKLIST}

\section{CAU 90: AREA 2 BITCUTTER CONTAINMENT - CAS 02-20-01: Bitcutter/PS Inj. Wells (3) (RCRA)}

4. Fences, gates, and signs (West Fenced Enclosure):

a. Is there damage to or a break in the fence?

b. Have any fenceposts been damaged or their anchoring weakened?

c. Is the gate intact and functional?

d. Does the gate show evidence of tampering or damage?

e. Was the gate locked?

f. Are any of the use restriction signs damaged or missing?

g. Are all use restriction signs legible?

h. How many use restriction signs need to be replaced?

i. Other?

5. Waste unit cover (West Fenced Enclosure):

a. Is there evidence of settling?

b. Is there evidence of cracking?

c. Is there evidence of erosion (wind or water)?

d. Is there evidence of human intrusion onto the cover?

e. Is there evidence of large animal intrusion onto the cover?

f. Is there evidence of animal burrowing?

g. Is vegetation growing on the cover?

h. Other (including trash, debris, etc within fenced area)?

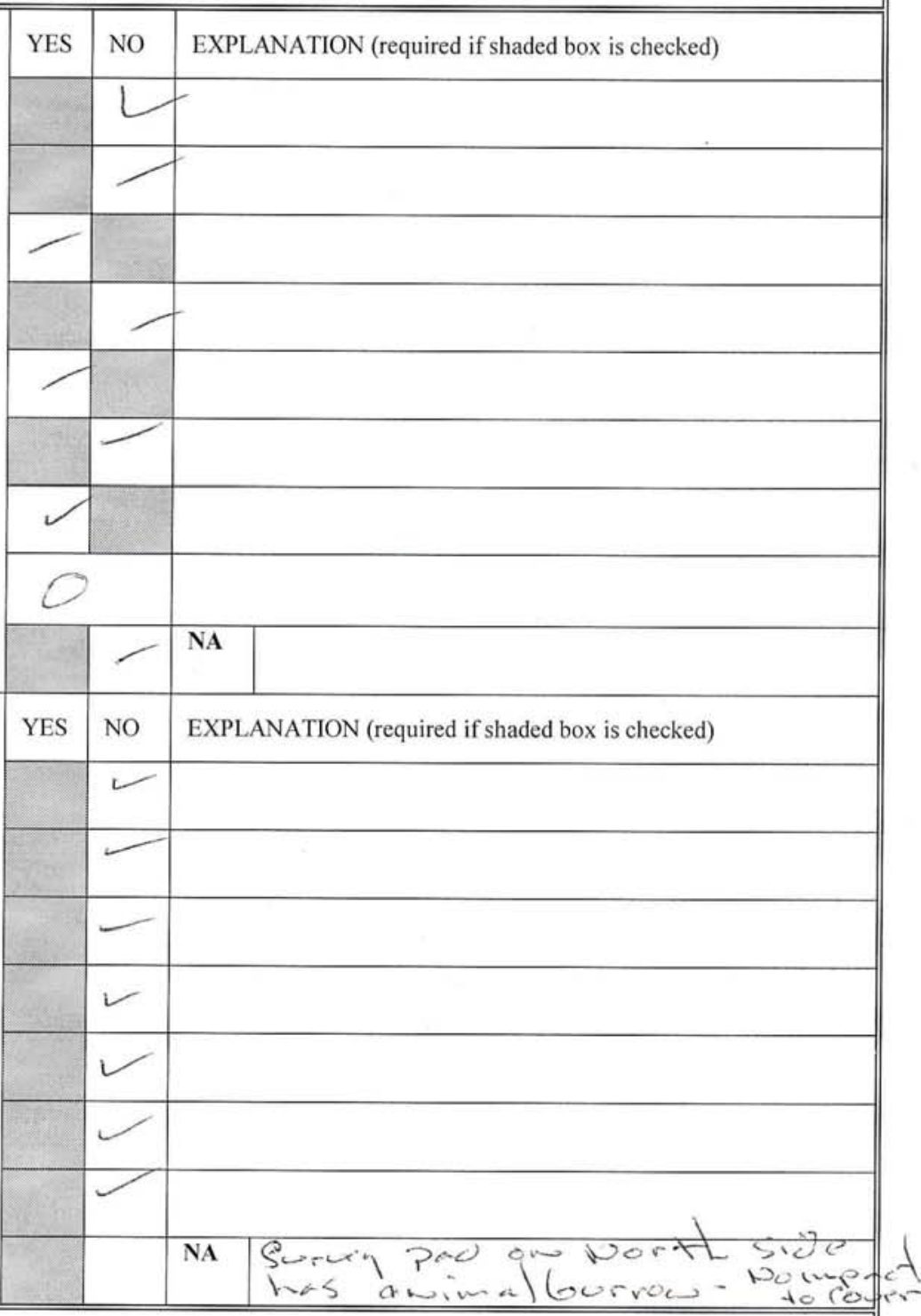

6. Photograph Instructions:

A total of 6 photographs are required to be taken during each inspection of CAU 90. Additional photographs may also be taken. The required photographs shall be taken as follows:

- Three (3) of the west unit from outside the fence, one in each compass direction (i.e., N, S, E) and

- Three (3) of the east unit from outside the fence, one in each compass direction (i.e., N, S, W)

7. Photograph Documentation:

a. Have all photographs been taken as required by the photograph instructions?

b. Has a photograph log been prepared?

c. How many photographs were taken?

d. Other?

\begin{tabular}{|l|l|l||}
\hline YES & NO & EXPLANATION (required if shaded box is checked) \\
\hline & & \\
\hline & & Log number: \\
\hline & & \\
\hline
\end{tabular}




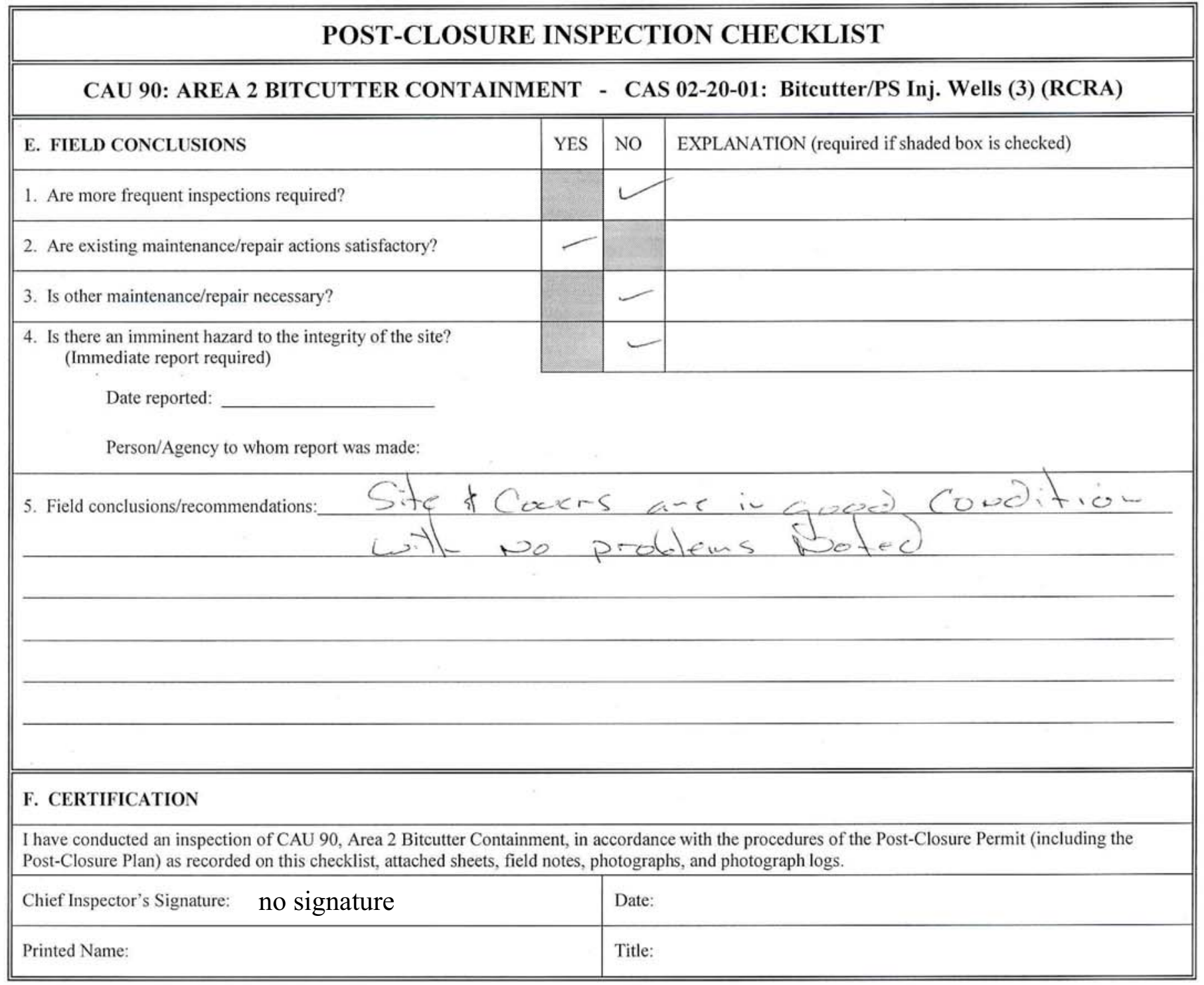

Attachments (check if attached):

$\square$ Field Notes

$\square$ Photos

$\square$ Maintenance records 


\section{POST-CLOSURE INSPECTION CHECKLIST}

\section{CAU 90: AREA 2 BITCUTTER CONTAINMENT - CAS 02-20-01: Bitcutter/PS Inj. Wells (3) (RCRA)}

\begin{tabular}{|c|c|}
\hline Inspection Date and Time: & Reason for Inspection: \\
\hline Date of Last Post-Closure Inspection: $\quad 121 / 8$ & Reason for Last Post-Closure Inspection: \\
\hline
\end{tabular}

Responsible Entity: NSTec Environmental Restoration, Nevada Test Site, Mercury, Nevada

Responsible Facility Owner: Thomas A. Thiele, Project Manager, Industrial Sites, Environmental Restoration Project

\begin{tabular}{|l|l|l}
\hline Chief Inspector: & Title: & Organization: Environmental Restoration \\
\hline Assistant Inspector: PaL/ Pew/t & Title: & Organization: Environmental Restoration \\
\hline
\end{tabular}

\section{A. GENERAL INSTRUCTIONS}

1. All checklist items must be completed and detailed comments made to document the results of the site inspection. The completed checklist is part of the field record of the inspection. Additional pages should be used as necessary to ensure that a complete record is made. Attach the additional pages and number all pages upon completion of the inspection.

2. Any checklist line item marked by an inspector in a SHADED BOX must be fully explained or an appropriate reference to previous reports provided. The purpose of this requirement is to provide a written explanation of inspector observations and the inspector's rationale for conclusions and recommendations. Explanations are to be placed on additional attachments and cross-referenced appropriately. Explanations, in addition to narrative, will take the form of sketches, measurements, and annotated site maps.

3. The site inspection is a walking inspection of the entire site including the perimeter and sufficient transects to be able to inspect the entire surface and all features specifically described in this checklist.

4. A standard set of color photographs is required. In addition, all anomalous features or new features (such as changes in adjacent area land use) are to be photographed. A photograph log entry will be made for each photograph taken.

5. Field notes taken to assist in completion of this checklist will become part of the inspection record. No form is specified for field notes; however, they must be legible and in sufficient detail to enable review by succeeding inspectors and the responsible agency.

6. This unit will be inspected semi-annually with formal reporting to the Nevada Division of Environmental Protection to be done annually. The annual report will include an executive summary, this inspection checklist with field notes and photograph $\log$ attached, and recommendations and conclusions.

\begin{tabular}{|c|c|c|c|c|}
\hline B. PREPARATION (To be competed prior to site visit) & YES & NO & \multicolumn{2}{|c|}{ EXPLANATION (required if shaded box is checked) } \\
\hline 1. Has the Post-Closure Permit been reviewed? & $x$ & & & \\
\hline 2. Has the Post-Closure Permit application been reviewed? & $x$ & & & \\
\hline \multicolumn{5}{|l|}{ 3. Has the Post-Closure Plan been reviewed? } \\
\hline \multicolumn{5}{|l|}{ 4. Have the site as-built plans and site base map been reviewed? } \\
\hline \multicolumn{5}{|l|}{ 5. Have the previous inspection reports been reviewed? } \\
\hline \multicolumn{2}{|l|}{ a. Were anomalies or trends detected on previous inspections? } & $x$ & & \\
\hline b. Was maintenance performed? & & mase & \multicolumn{2}{|c|}{ 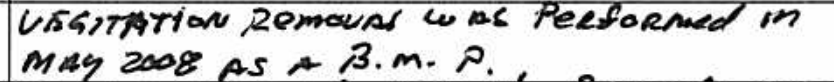 } \\
\hline $\begin{array}{l}\text { If maintenance was performed, has a copy of the } \\
\text { maintenance records been obtained? }\end{array}$ & & & $\stackrel{N A}{X}$ & 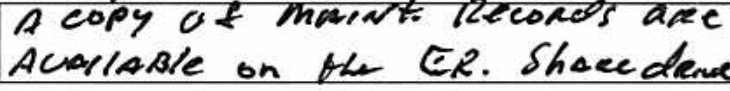 \\
\hline \multirow[b]{2}{*}{$\begin{array}{l}\text { a. If so, has site repair resulted in a change from as-built } \\
\text { conditions? }\end{array}$} & 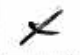 & & & \\
\hline & & & NA & \\
\hline $\begin{array}{l}\text { b. If yes (to } 6 \mathrm{a} \text { ), are revised as-built plans available that reflect } \\
\text { repair changes? }\end{array}$ & & & $\begin{array}{l}\text { NA } \\
X\end{array}$ & \\
\hline
\end{tabular}




\section{POST-CLOSURE INSPECTION CHECKLIST}

\section{CAU 90: AREA 2 BITCUTTER CONTAINMENT - CAS 02-20-01: Bitcutter/PS Inj. Wells (3) (RCRA)}

\section{SITE INSPECTION PREPARATION}

Assemble the following, as needed, to conduct inspections:
a. Camera, film, and batteries
b. Keys to locks
c. Clipboard
d. Tape measure
e. Radio, pager, etc.
f. Previous Post-Closure Report, Inspection Checklists, repair records, and as-built plans
g. Other miscellaneous support equipment

\section{SITE INSPECTION}

1. Adjacent off-site features:

a. Are there any new activities or features in the vicinity that could potentially affect the site (e.g., activities that change the flow of surface water or are encroaching the unit)?

2. Fences, gates, and signs (East Fenced Enclosure):

a. Is there damage to or a break in the fence?

b. Have any fenceposts been damaged or their anchoring weakened?

c. Is the gate intact and functional?

d. Does the gate show evidence of tampering or damage?

e. Was the gate locked?

f. Are any of the use restriction signs damaged or missing?

g. Are all use restriction signs legible?

h. How many use restriction signs need to be replaced?

i. Other?

3. Waste unit cover (East Fenced Enclosure):

a. Is there evidence of settling?

b. Is there evidence of cracking?

c. Is there evidence of erosion (wind or water)?

d. Is there evidence of human intrusion onto the cover?

e. Is there evidence of large animal intrusion onto the cover?

f. Is there evidence of animal burrowing?

g. Is vegetation growing on the cover?

h. Other (including trash, debris, etc within fenced area)?

\begin{tabular}{|c|c|c|}
\hline YES & NO & EXPLANATION (required if shaded box is checked) \\
\hline & $x$ & \\
\hline \multirow[t]{3}{*}{ YES } & NO & EXPLANATION (required if shaded box is checked) \\
\hline & $x$ & \\
\hline & $x$ & \\
\hline$x$ & & \\
\hline & $x$ & \\
\hline$x$ & & \\
\hline & $\ell$ & 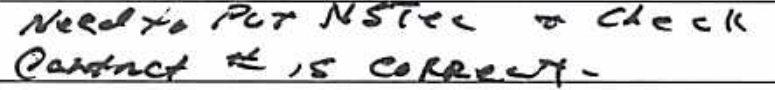 \\
\hline & & $\stackrel{\text { NA }}{X}$ \\
\hline YES & NO & EXPLANATION (required if shaded box is checked) \\
\hline & X & \\
\hline & $x$ & \\
\hline & $\gamma$ & \\
\hline & $x$ & \\
\hline & 火 & \\
\hline X & & Light veg, cauld Be Remazoul \\
\hline & X & NA \\
\hline
\end{tabular}




\section{POST-CLOSURE INSPECTION CHECKLIST}

\section{CAU 90: AREA 2 BITCUTTER CONTAINMENT - CAS 02-20-01: Bitcutter/PS Inj. Wells (3) (RCRA)}

4. Fences, gates, and signs (West Fenced Enclosure):

a. Is there damage to or a break in the fence?

b. Have any fenceposts been damaged or their anchoring weakened?

c. Is the gate intact and functional?

d. Does the gate show evidence of tampering or damage?

e. Was the gate locked?

f. Are any of the use restriction signs damaged or missing?

g. Are all use restriction signs legible?

h. How many use restriction signs need to be replaced?

i. Other?

5. Waste unit cover (West Fenced Enclosure):

a. Is there evidence of settling?

b. Is there evidence of cracking?

c. Is there evidence of erosion (wind or water)?

d. Is there evidence of human intrusion onto the cover?

e. Is there evidence of large animal intrusion onto the cover?

f. Is there evidence of animal burrowing?

g. Is vegetation growing on the cover?

h. Other (including trash, debris, etc within fenced area)?

\begin{tabular}{|c|c|c|}
\hline \multirow[t]{3}{*}{ YES } & No & EXPLANATION (required if shaded box is checked) \\
\hline & $X$ & \\
\hline & $y$ & \\
\hline 7 & & \\
\hline & 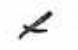 & \\
\hline$\alpha$ & & \\
\hline & $x$ & \\
\hline 4 & gMS & 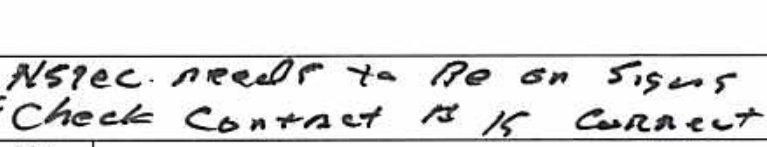 \\
\hline & & \begin{tabular}{l|l} 
NA & \\
\end{tabular} \\
\hline YES & NO & EXPLANATION (required if shaded box is checked) \\
\hline & $x$ & \\
\hline & $x$ & \\
\hline & $x$ & \\
\hline & $x$ & \\
\hline & $x$ & \\
\hline & $x$ & \\
\hline x & & Uapr, reedor to $\mathrm{Be}$ removesh \\
\hline & $x$ & NA \\
\hline
\end{tabular}

6. Photograph Instructions:

A total of 6 photographs are required to be taken during each inspection of CAU 90. Additional photographs may also be taken. The required photographs shall be taken as follows:

- Three (3) of the west unit from outside the fence, one in each compass direction (i.e., N, S, E) and

- Three (3) of the east unit from outside the fence, one in each compass direction (i.e., N, S, W).

7. Photograph Documentation:

a. Have all photographs been taken as required by the photograph instructions?

b. Has a photograph log been prepared?

c. How many photographs were taken?

d. Other?

\begin{tabular}{|c|c|c|}
\hline YES & NO & EXPLANATION (required if shaded box is checked) \\
\hline$x$ & & \\
\hline$x$ & & Log number: \\
\hline \multicolumn{3}{|c|}{6} \\
\hline & & ${ }_{\mathrm{N}}^{\mathrm{A}}$ \\
\hline
\end{tabular}




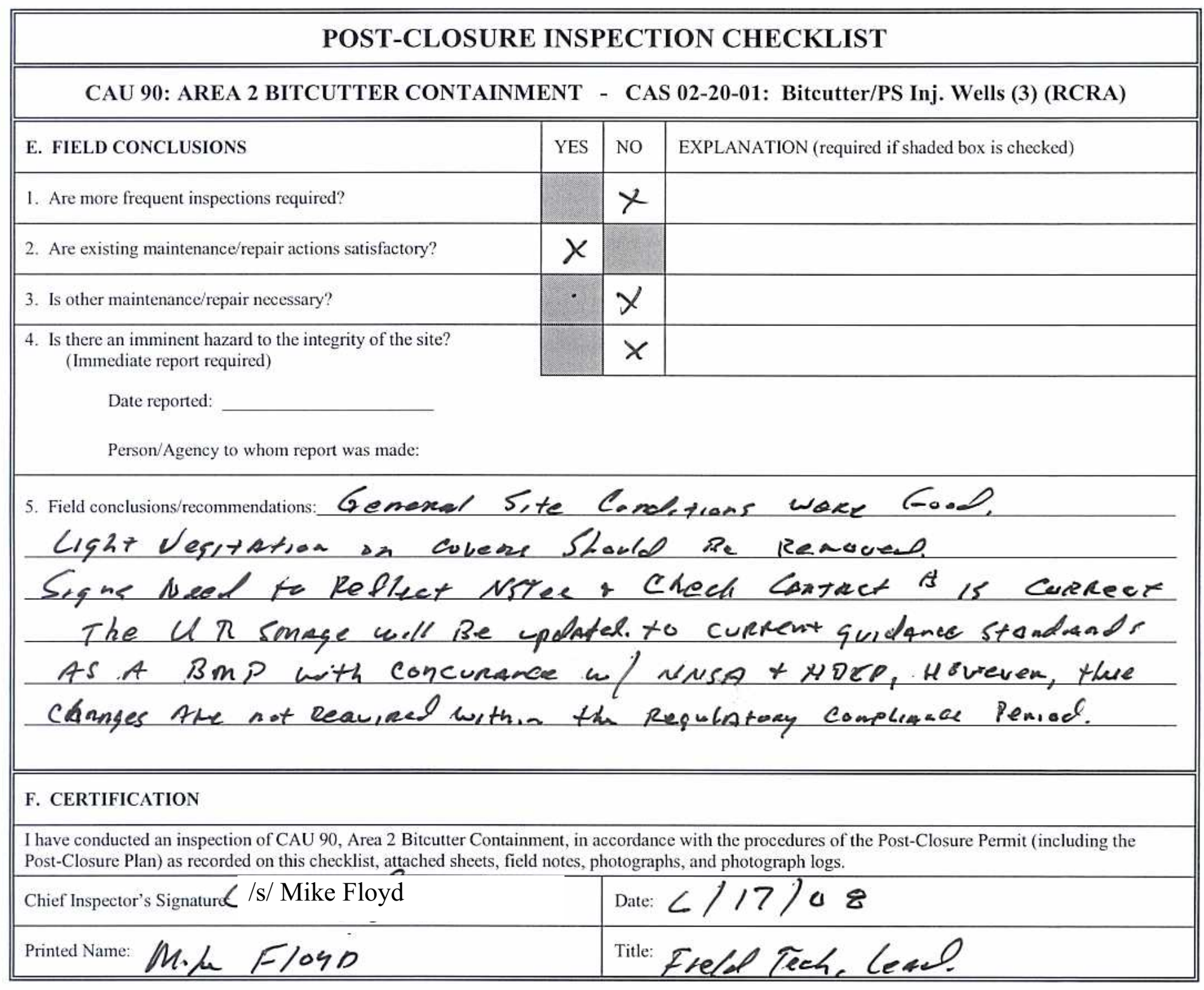

Attachments (check if attached):
¿ Field Notes
$\triangle$ Photos
$\square$ Maintenance records 
CAU 90 Post-Closure Report

Revision: 0

Date: September 2008

\section{APPENDIX B}

\section{FIELD NOTES}


CAU 90 Post-Closure Report

Revision: 0

Date: September 2008

THIS PAGE INTENTIONALLY LEFT BLANK 
PROJECT NO.

169

TITLE

BOOK NO.

Work continued from Page

(CA4 92) Area 6 Devon Pond Precipitation Inspection

$12 / 11 / 07$

Scope :

Arrived \& 1:07 PM to inspect level of precipitation on the waste unit cover. Received an email notification from the UCC MEDA Station 5 that the level of precipitation exceeded our regulatory threshold of $0.5 \mathrm{in}$ on $12 / 8 / 07$ (Saturday). The precipitation event reached a level of $0.8 \mathrm{in}$.

Personnel: Glenn Richardson, Task Manager Equipment: Camera, Radio 10 Dudley Ever, Sr. Scientist

Performed a site walk down around the Deon Pond fenced area. Noticed standing water inside the NE comer of the fenced area, but was not observed on the waste unit cover. The fencing and UR signage is in good condition, 15 Also, the wave barriers are not damaged and appear to be maintaining their stability. The site is in great condition and was not adversely affected by the precipitation event. There are no issues or concerns associated with this site. Leaving the site at H:23 PM

/s/ Glenn Richardson

20

RCRA Post Closure Inspections - December 18, 2007

25

Personnel: Glenn Kichardson-NSTec Task Mgr.

Dudley Ever - NSTec Senior Scientist, Greg Doyle-NSTec Engine Geol.gi:

Visitors: Ted Zaferatos - NDEP

Kevin Cable, Janis Rom - NNSA

SCIENTIFIC BINDERY PRODUCTIONS CHICAGO 60605 Made in USA

Work continued to Page 170

signature /s/ Glenn Richardson

ATE

$12 / 18 / 07$

DISCLOSED TO AND UNDERSTOOD BY

DATE

WITNESS

DATE 
170

PROJECT NO.

BOOK NO.

Work continued from Page 169

Scope: Perform quarterly and semiannual post closure site inspections for the following CAUs: $90,92,110,+112$

Equipment: Camera

Weather Conditions: Cloudy, Extremely Low -Mid 30 's

PPE: Standard Level $\triangle$ (hard hats are optional)

8:55 AM - Left Mercury in Route to Area 2 Bitcutter Site 9:38 AM -Arrived Q CAM 90 Bitcutter

Performed a Tailgate Safety Briefing w/NNSA + NDEP.

- Discussed Cold Stress conditions, Slips/trips/fall hazards

- "balanced consumption of water to prevent dehydration

- "buddy system during walkdown

9:45 AM - Performed site inspection @ CAU 90. Overall site conditions are good. There are no signs of vegetation growth. The chain link fencing and signage are in good condition. Noticed a small animal burrow inside the west fenced areas however, this not significant enough to warrant a corrective action. 9:54 AM - Leaving CAU 90 in route to CAU 110 U3ax/bl. 10:10AM-Arrived@CAn110 and started site inspection. Greg Doyle met us at the site and participated in the site inspection. The fencing and signage looked good and was well-maintained. There were a few animal burrows identified. A followup action will be taken to contact $D$. Anderson (ecological services) to plan a sitevisprior to the March inspection period. We also discovered a new crack greater than $6 \mathrm{ft}$. on the surface (lateral extent) on the east edge of the cover. Photos were taken for documentation and repair is necessary within 60 days. After discussing our observations CIENTIFIC BINDERY PRODUCTIONS CHICAGO 60605 Made in USA

Work continued to Page 171 SIGNATURE /s/ Glenn Richardson DISCLOSED TO AND UNDERSTOOD BY

DATE WITNESS

DATE

$12 / 18 / 07$ 


\section{TITLE}

Work continued from Page 170

BOOK NO.

with NNSA and NDEP, we departed the sife in route to CAU9Z. Greg Doyle returned to Mercury after the 110 inspection.

11:18AM-ArriveJ @ CAU 92 and performed sife inspection. Overall site conditions are great. The fencing and UR signage 5 are well maintained. No evidence of vegetation growth. The wave barriers are not damaged. Photo documentation was taken at this site. No issues or concerns. Left CAL 92 in route to CAL 112 .

12:02 PM-Arrived $\odot C A U \| Z$ and performed a site inspection. Drowe around Area 23 waste trenches to find no observations that warranted a corrective action. The URsignsand aboveground monuments are in good condition. No evidence of vegetation growth. LefA CAUIIZ and headed to ER Dorms. and NDEP. NNSA + NDEP left the Sorms in route to Mereury. End of Inspections at 12:15PM.

Note: Photosthwere faken will be

/s/ Glenn Richardson

SCIENTIFIC BINDERY PRODUCTIONS CHICAGO 60605 Made in USA

/s/ Glenn Richardson
SIGNATURE

Work continued to Page

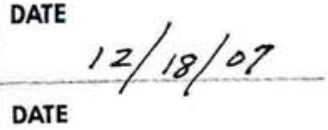


164 TITLE

PROJECT NO.

Work continued from Page

$6 / 17 / 08$

BOOK NO.

RCRA IUSPECTION

MSTec

mike Flo9n - FTC

PACl Dewitt - DP.M.

Paul Pever - pet.
Vusitoas

Keun CnBBK - DOE

Ted Z - STHE

CAL 9O-BITCATter

1000-ARnive on Locneten, tAlle nlout Snfis,

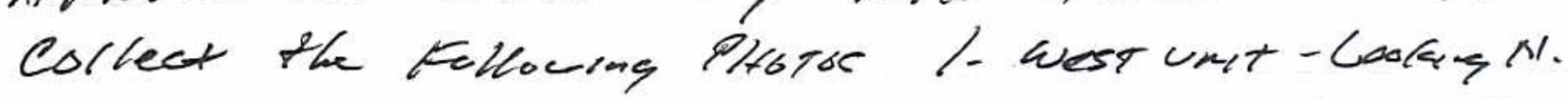

$\cos k$ ing $\theta^{n}$.

Coolang 5

2. ERST centi-luoking 5 ,

lookeny led

lookens 210

Lighr Vegiration upon Bork knots. needs 2 a Be Remond. Clatnge Sisw on Both to Reflect Xistec + Chack Phowe to Be swre it is Downect. Signs, Fencerm, Goter, Profs were Fornd to Be in good Condition ald locked

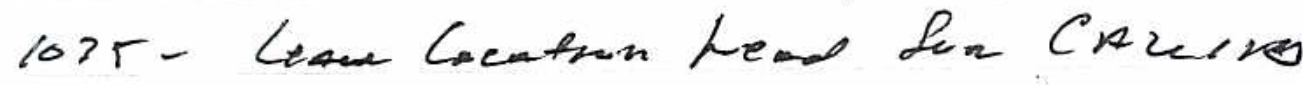

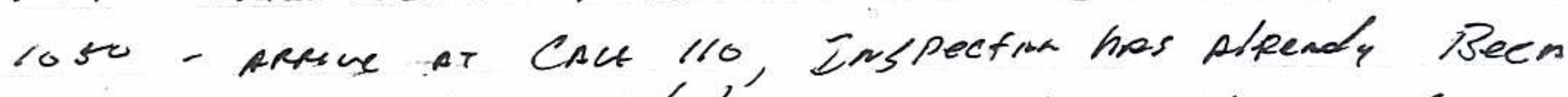
Complested on 6/5/08. qoing to walke the fith LI Ted a kevin.

1115 - Conumg CAuiro, Forng to Decon Pand, wo issuer or Concenar at cau 116.

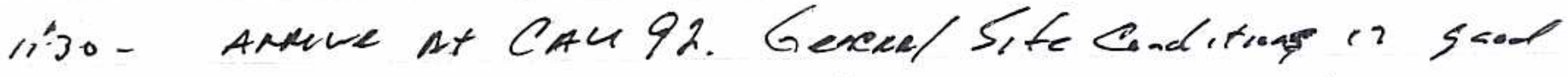

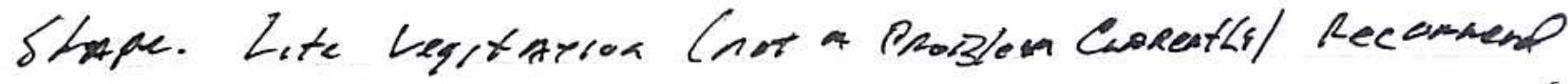

SIGNATURE, /s/ Mike Floyd

DISCLOSED TO AND UNDERSTOOD BY
Work continued to Page / $\mathrm{Cr}$

Dane $/ 12 / 08$ 
TITLE

Work continued from Page $164 \quad 6 / 17 / 68$
PROJECT NO. RCAN ENSPedA65 BOOK NO.

1130 court. I Spraying lo/thessiside to pensee then in the

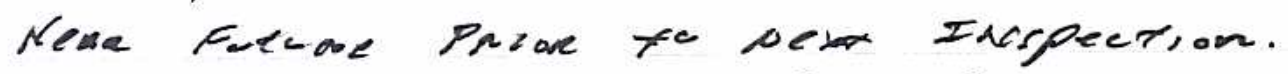

$1155-$ Learn Con 92, Head for Can 112

1220 - Arrive at call II2, Site cons faunal to Be in

5 Good Conation, 2 signs on the worth sole were have meal need to be pe trucked, Bur over all site Condition was found to be in gaud Condertere

1235- Revues to Dour

10

15

/s/ M Floyd

20

25

www.scientificbinderv88vrs.com

SIGNATURE

/s/ Mike Floyd

DISCLOSED TO AND UNDERSTOOD BY Y
DATE

WITNESS

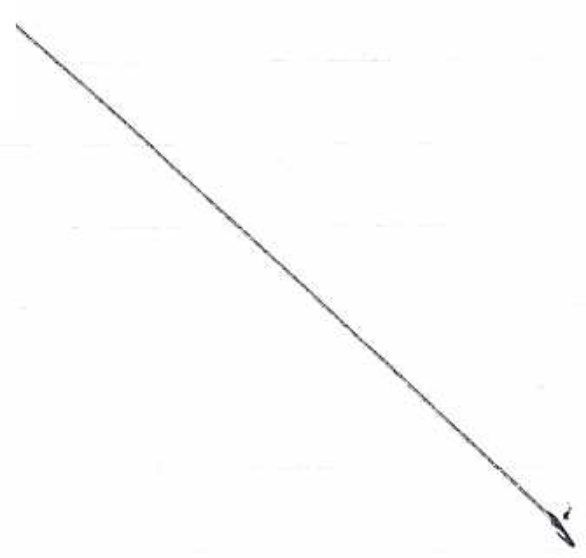

Work continued to Page

DATE 
CAU 90 Post-Closure Report

Revision: 0

Date: September 2008

THIS PAGE INTENTIONALLY LEFT BLANK 
CAU 90 Post-Closure Report

Revision: 0

Date: September 2008

\section{APPENDIX C}

\section{INSPECTION PHOTOGRAPHS}


CAU 90 Post-Closure Report

Revision: 0

Date: September 2008

THIS PAGE INTENTIONALLY LEFT BLANK 


\section{Photograph Log}

\begin{tabular}{|c|c|l|}
\hline $\begin{array}{c}\text { PhOtOGRAPH } \\
\text { Number }\end{array}$ & DATE & \multicolumn{1}{c|}{ DesCRIPTION } \\
\hline \hline 1 & $12 / 18 / 2007$ & View of west unit looking north \\
\hline 2 & $12 / 18 / 2007$ & View of west unit looking east \\
\hline 3 & $12 / 18 / 2007$ & View of west unit looking south \\
\hline 4 & $12 / 18 / 2007$ & View of east unit looking south \\
\hline 5 & $12 / 18 / 2007$ & View of east unit looking west \\
\hline 6 & $12 / 18 / 2007$ & View of east unit looking north \\
\hline 7 & $6 / 17 / 2008$ & View of west unit looking north \\
\hline 8 & $6 / 17 / 2008$ & View of west unit looking east \\
\hline 9 & $6 / 17 / 2008$ & View of west unit looking south \\
\hline 10 & $6 / 17 / 2008$ & View of east unit looking south \\
\hline 11 & $6 / 17 / 2008$ & View of east unit looking west \\
\hline 12 & $6 / 17 / 2008$ & View of east unit looking north \\
\hline
\end{tabular}


CAU 90 Post-Closure Report

Revision: 0

Date: September 2008

THIS PAGE INTENTIONALLY LEFT BLANK 
Date: September 2008

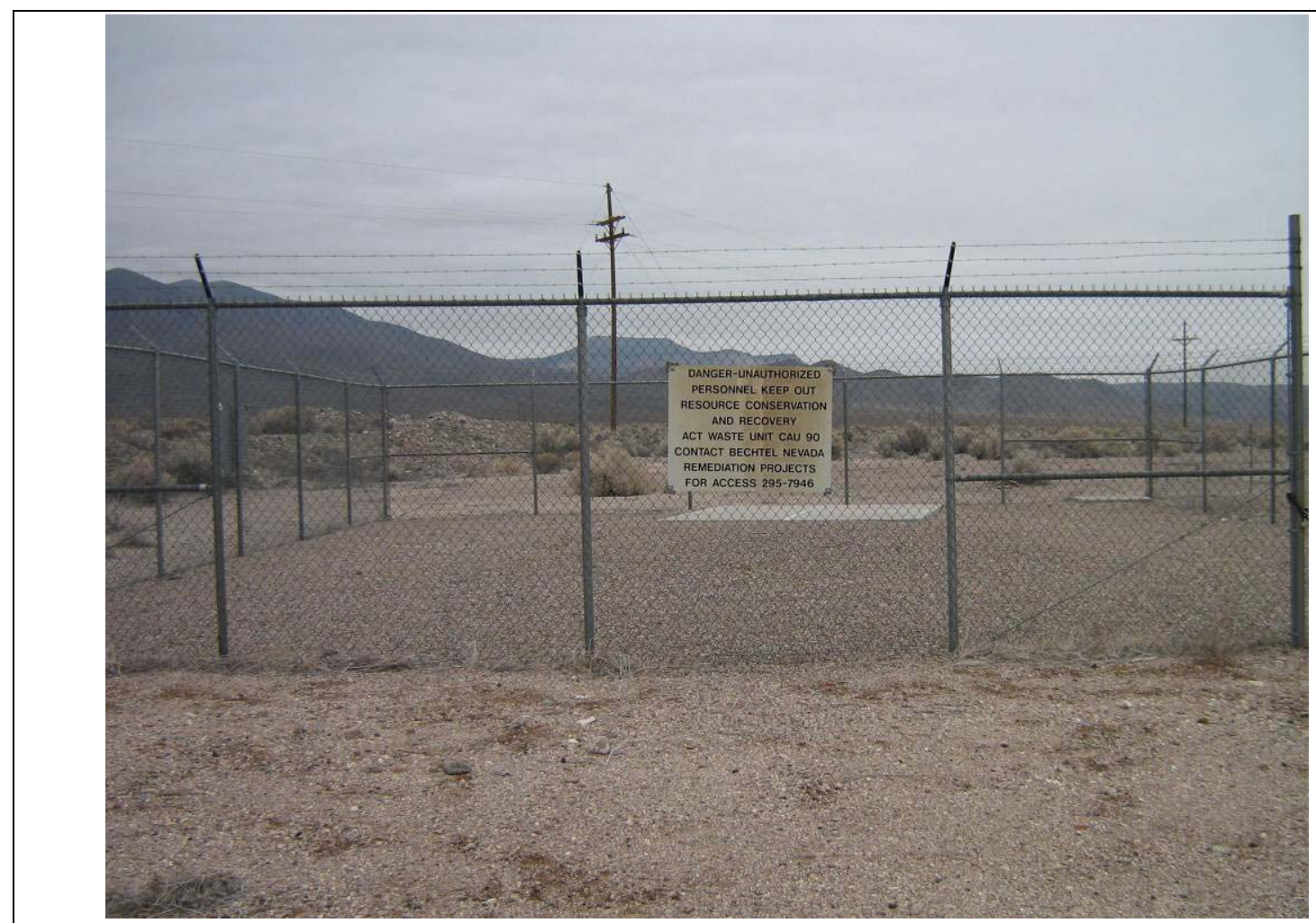

Photograph 1: View of west unit looking north, 12/18/2007

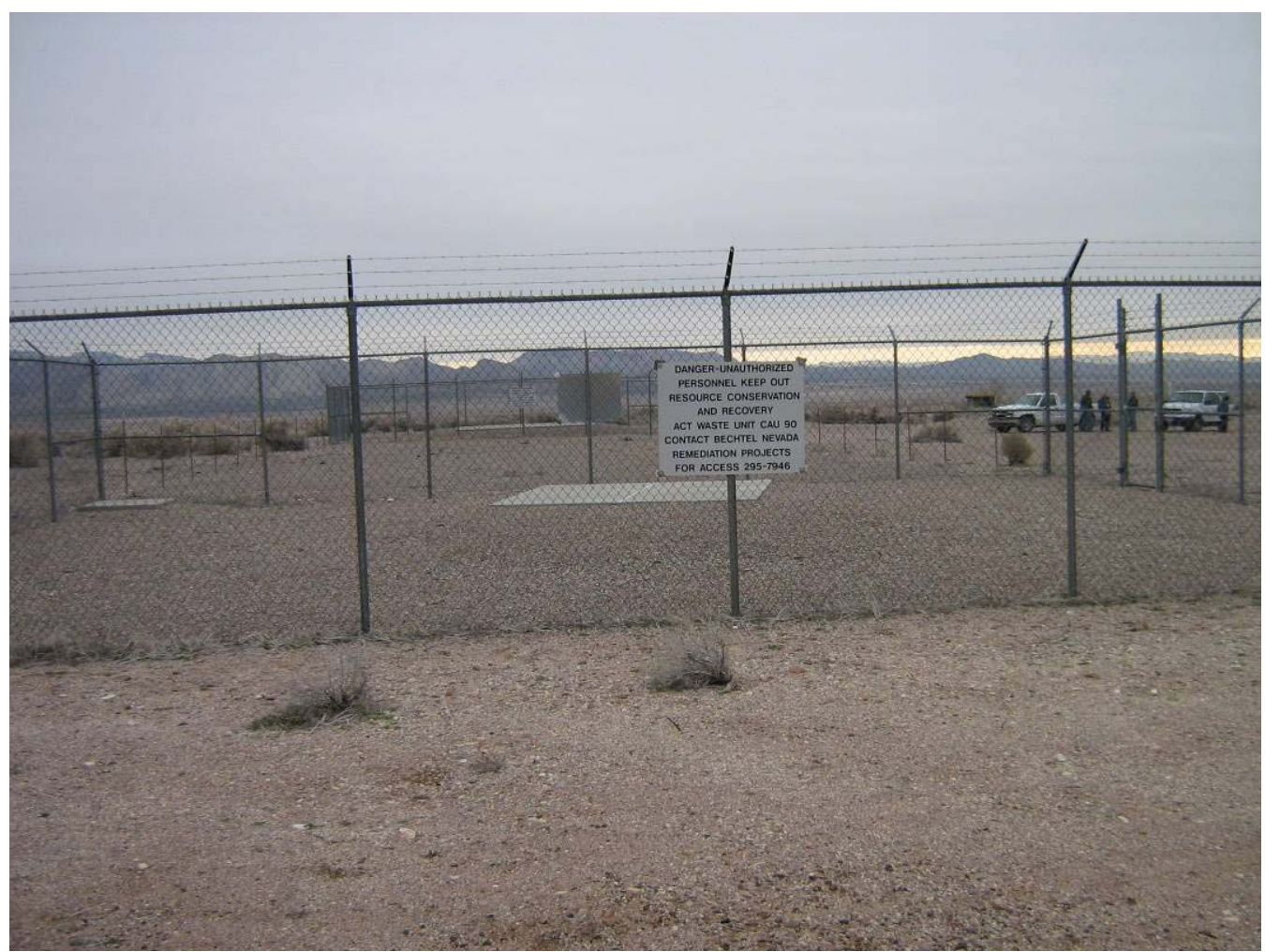

Photograph 2: View of west unit looking east, 12/18/2007 


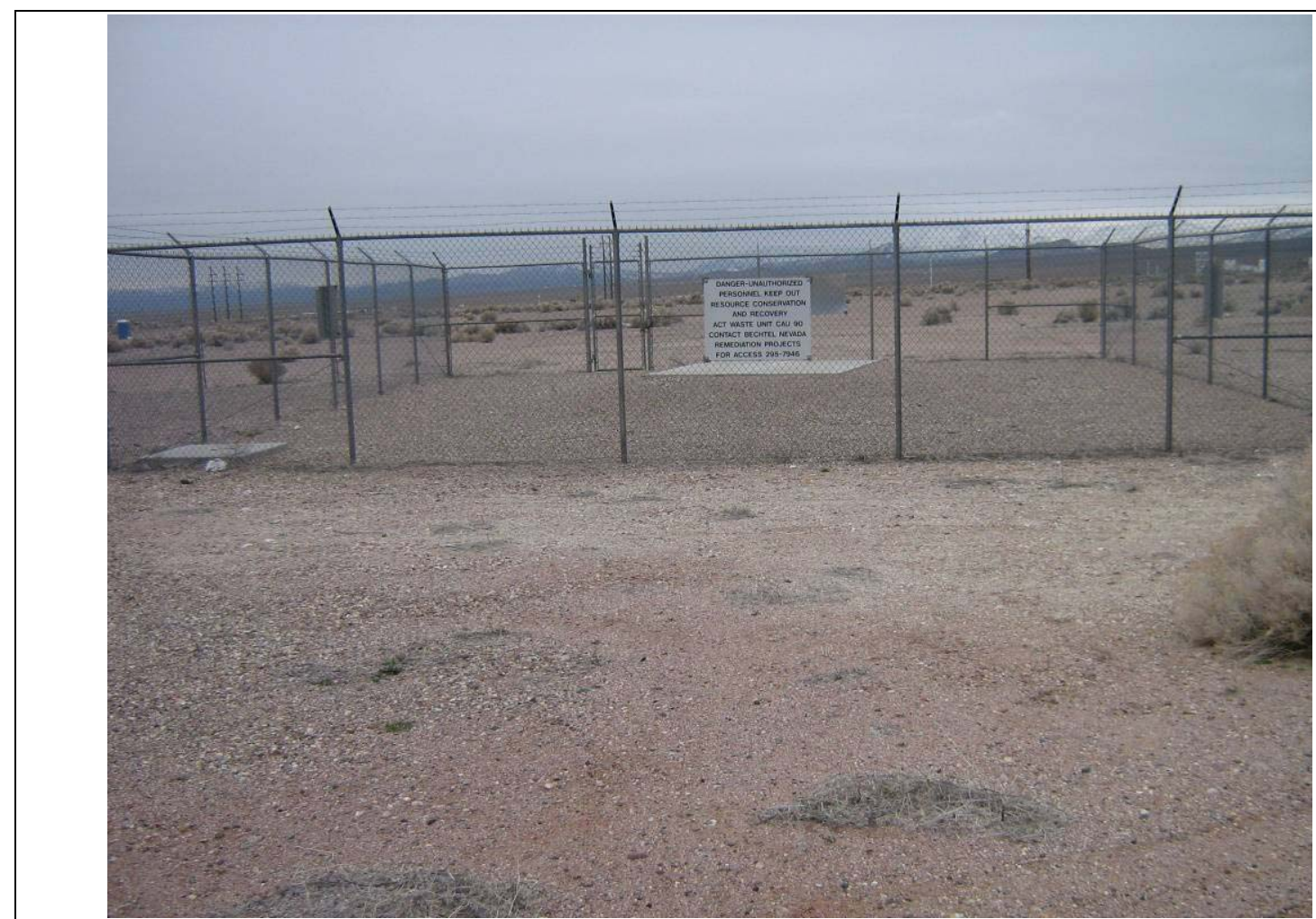

Photograph 3: View of west unit looking south, 12/18/2007

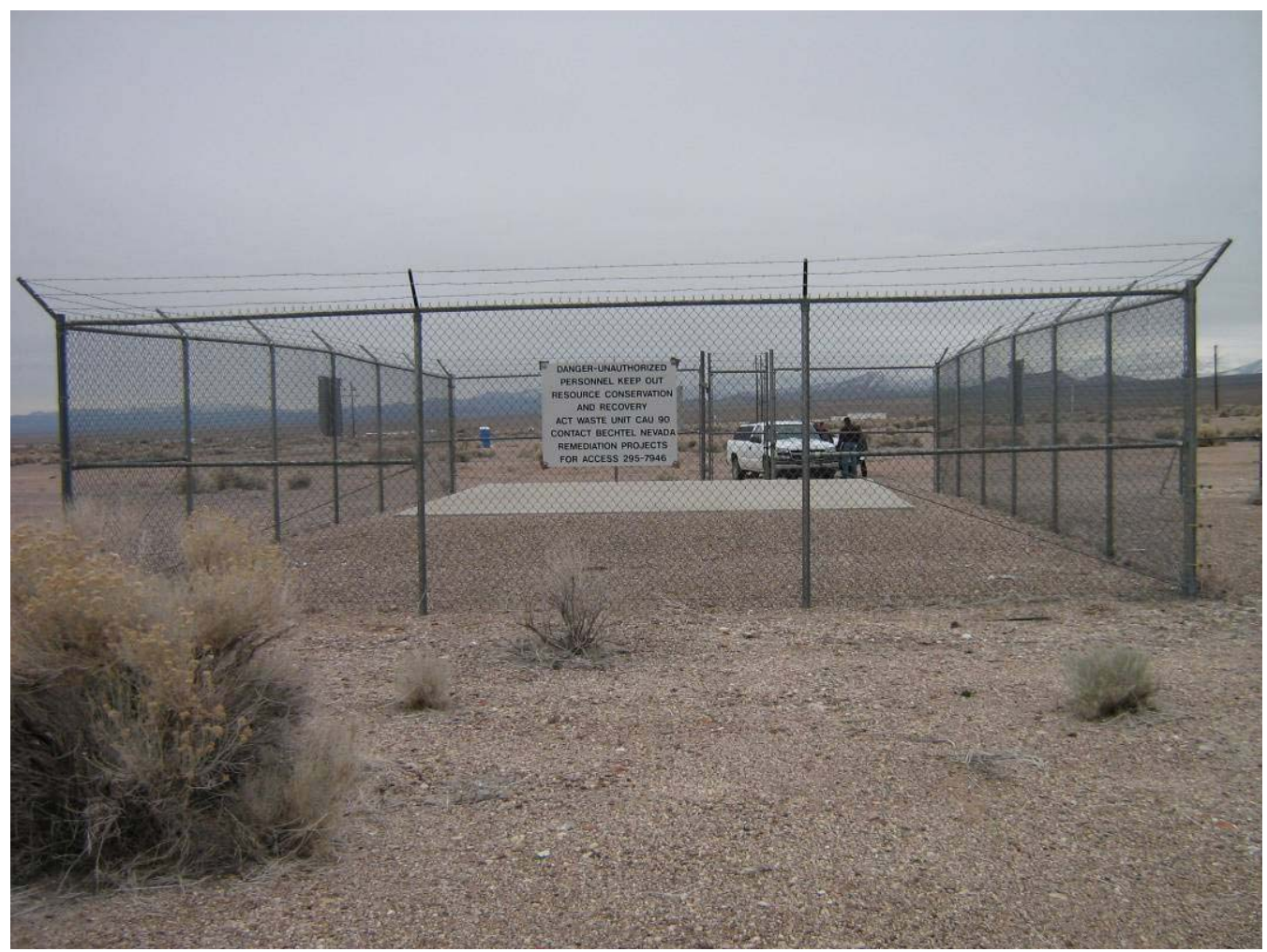

Photograph 4: View of east unit looking south, 12/18/2007 


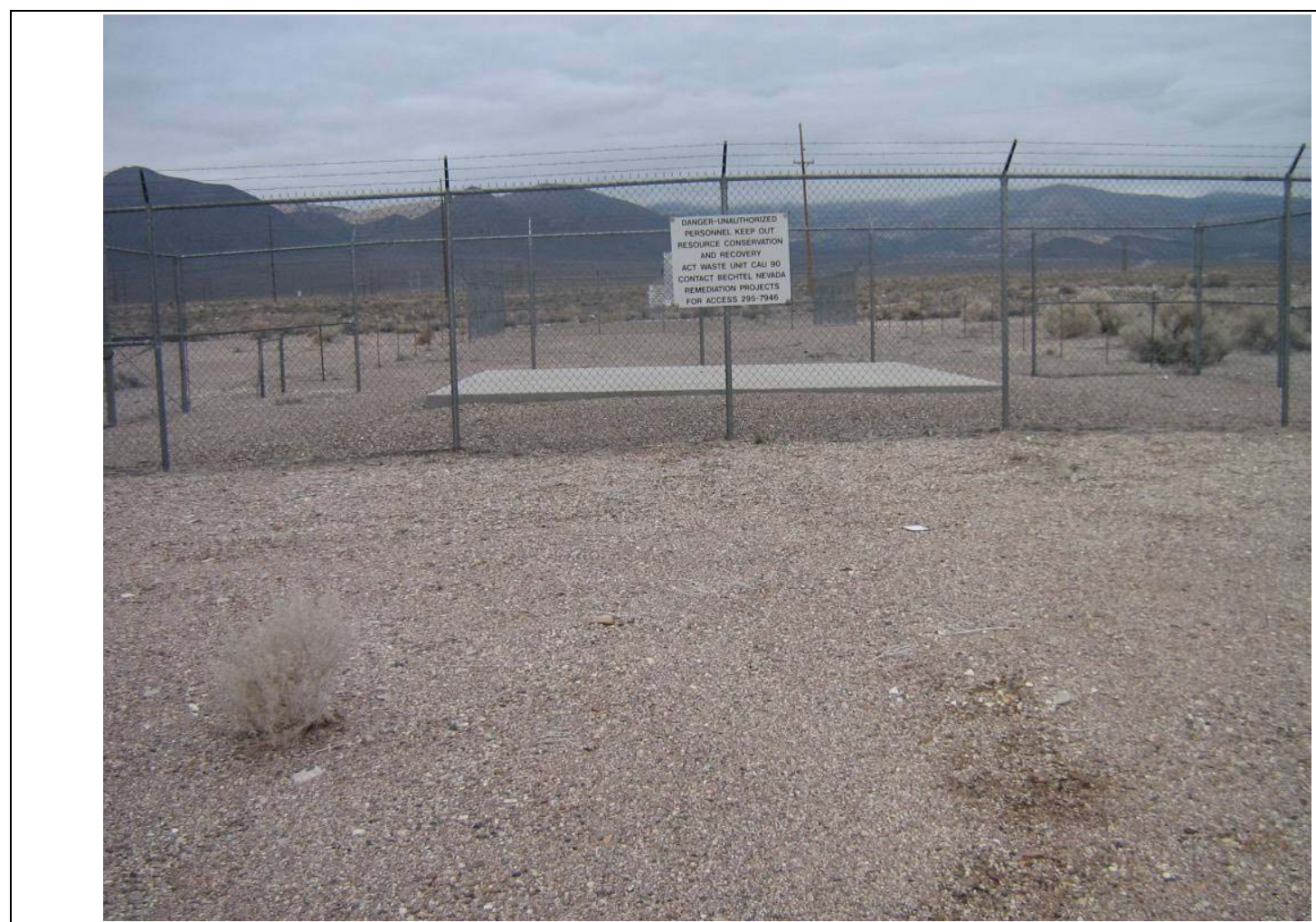

Photograph 5: View of east unit looking west, 12/18/2007

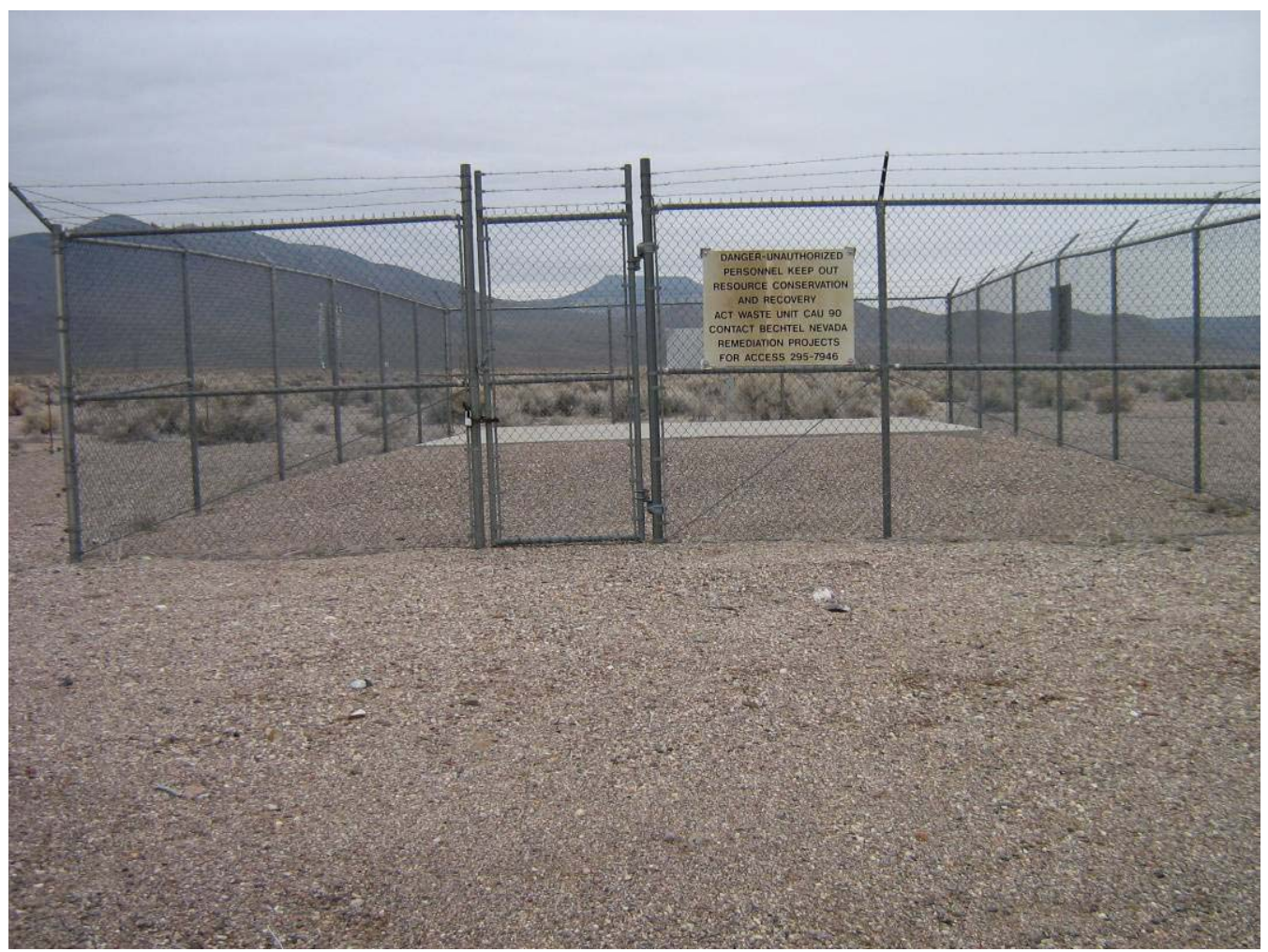

Photograph 6: View of east unit looking north, 12/18/2007 


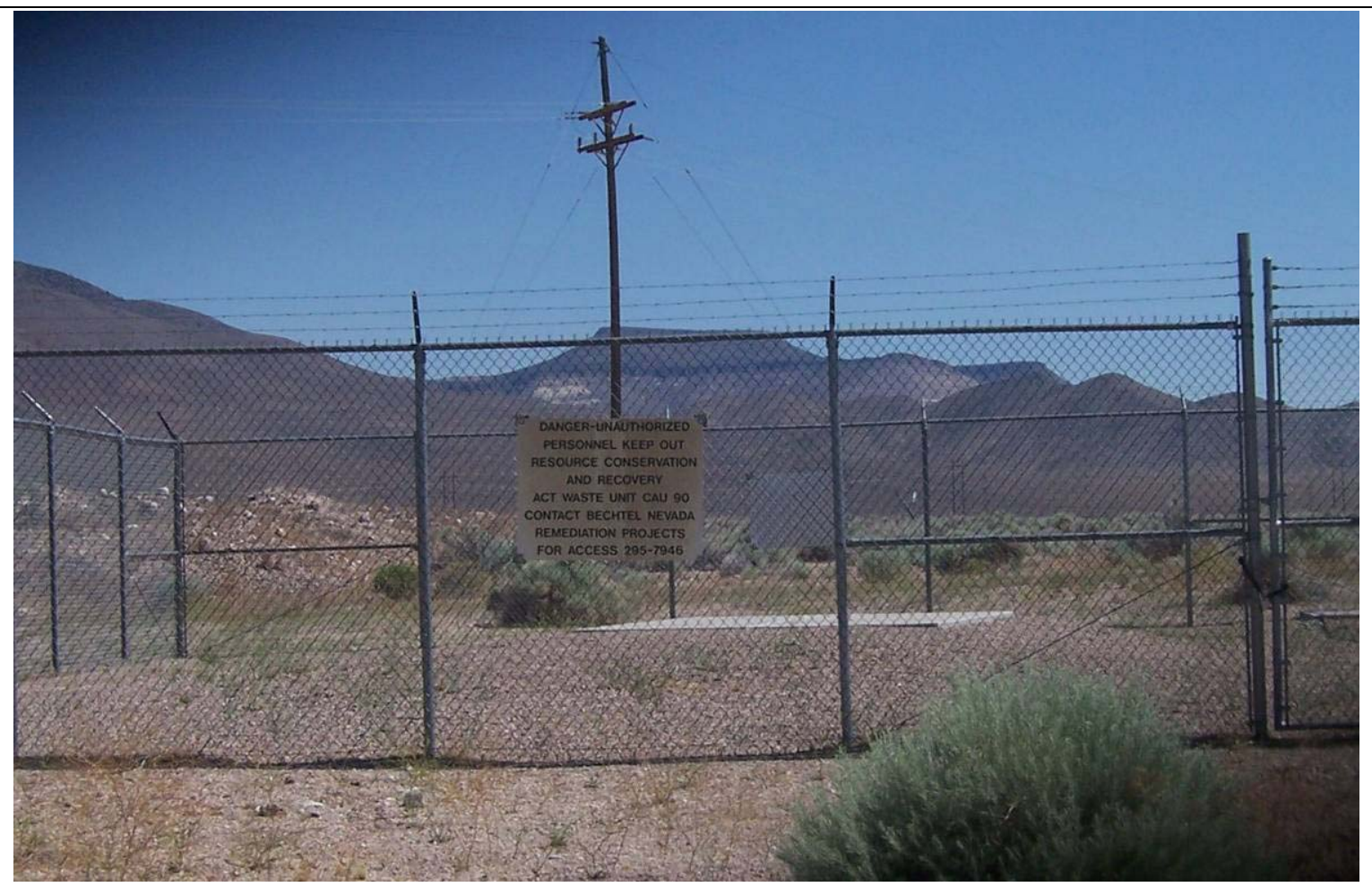

Photograph 7: View of west unit looking north, 6/17/2008

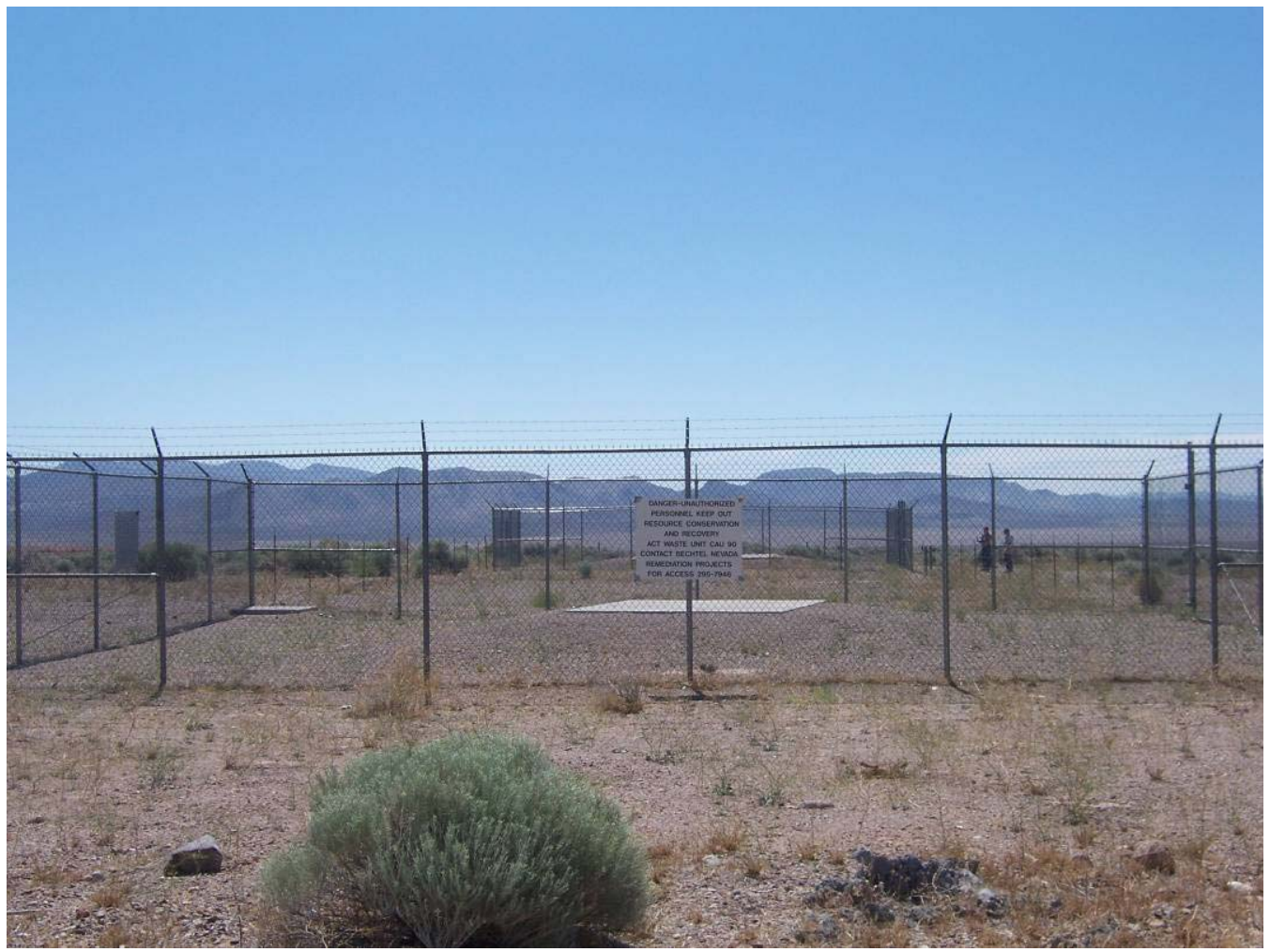

Photograph 8: View of west unit looking east, 6/17/2008 


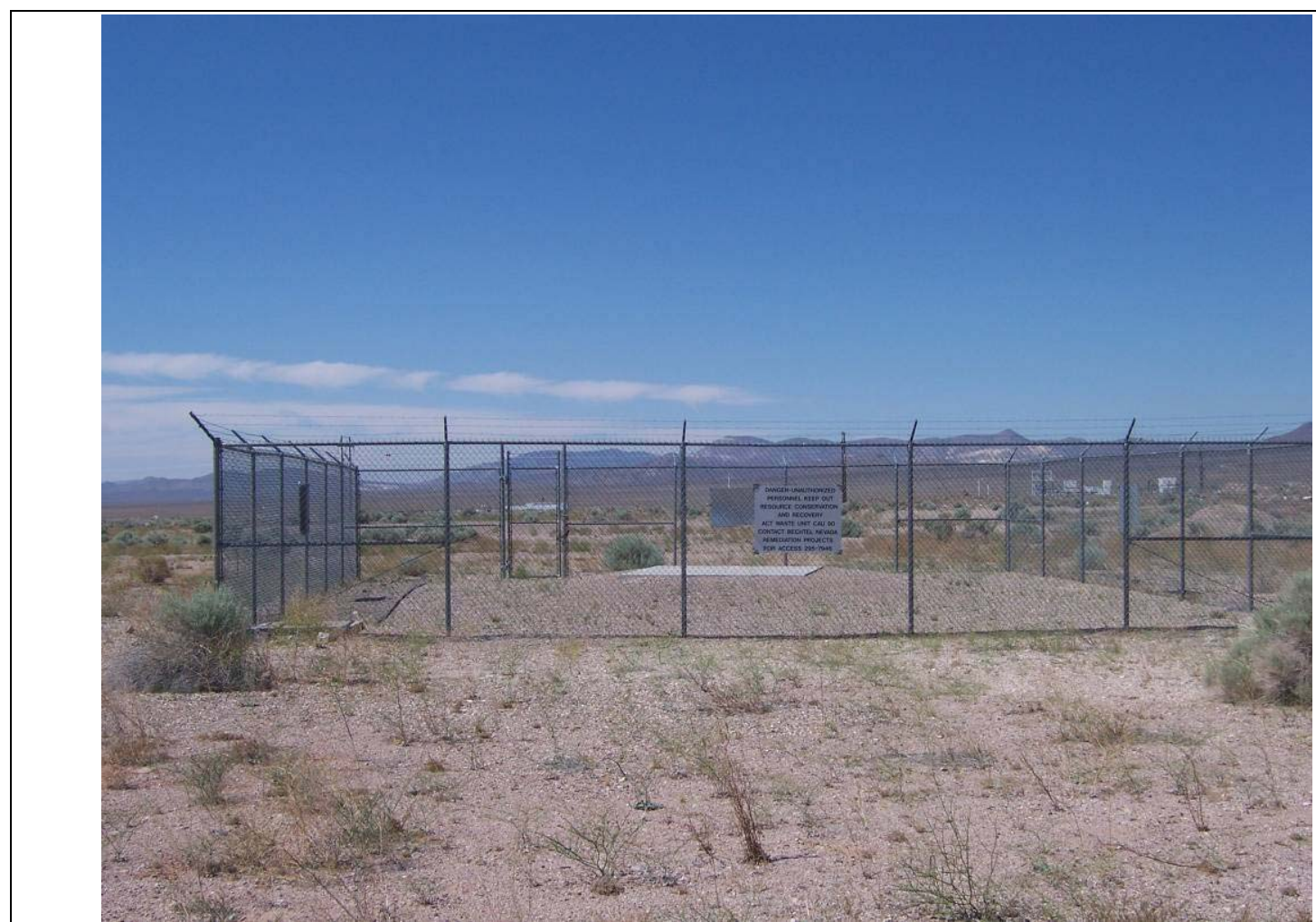

Photograph 9: View of west unit looking south, 6/17/2008

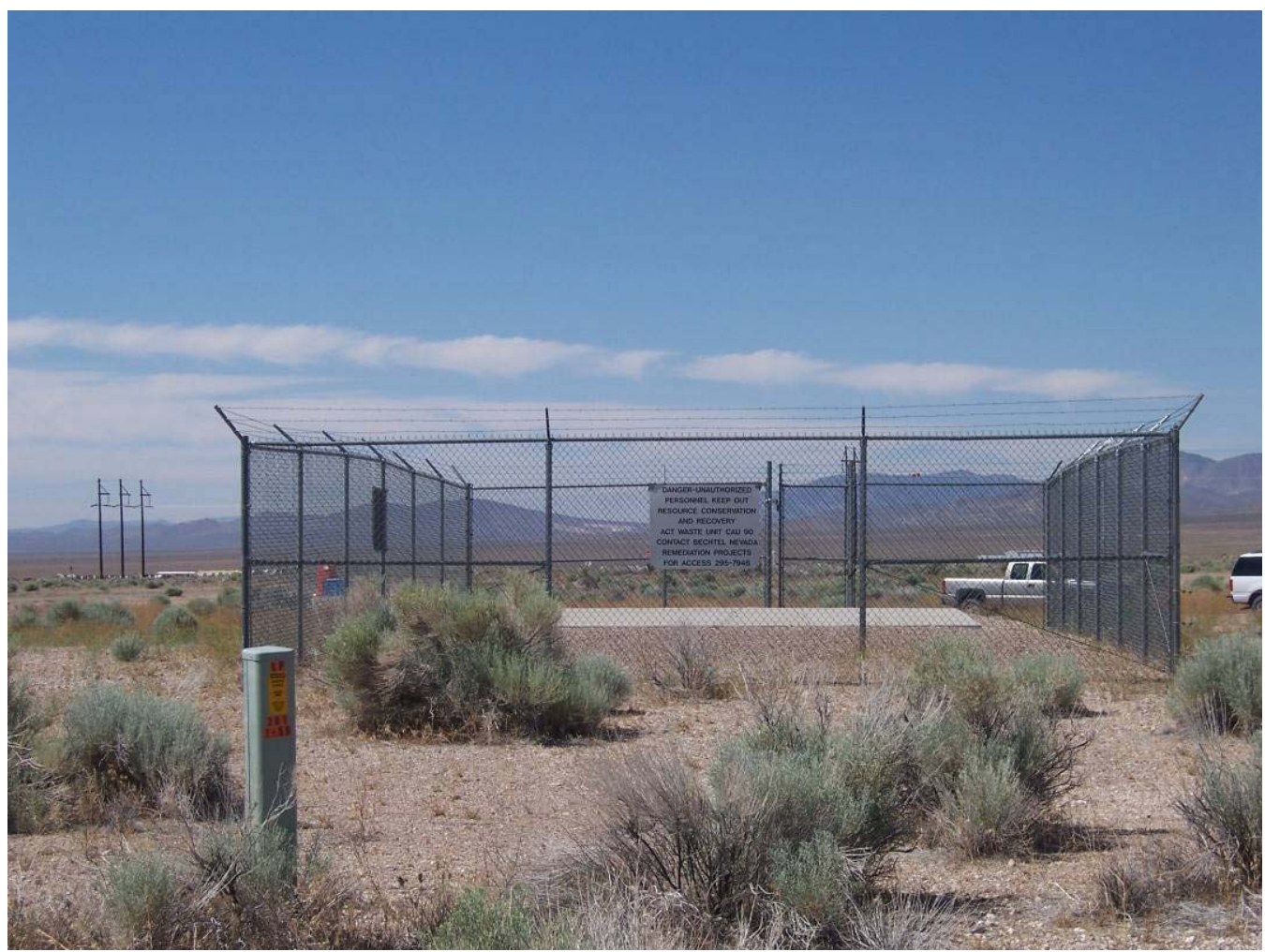

Photograph 10: View of east unit looking south, 6/17/2008 


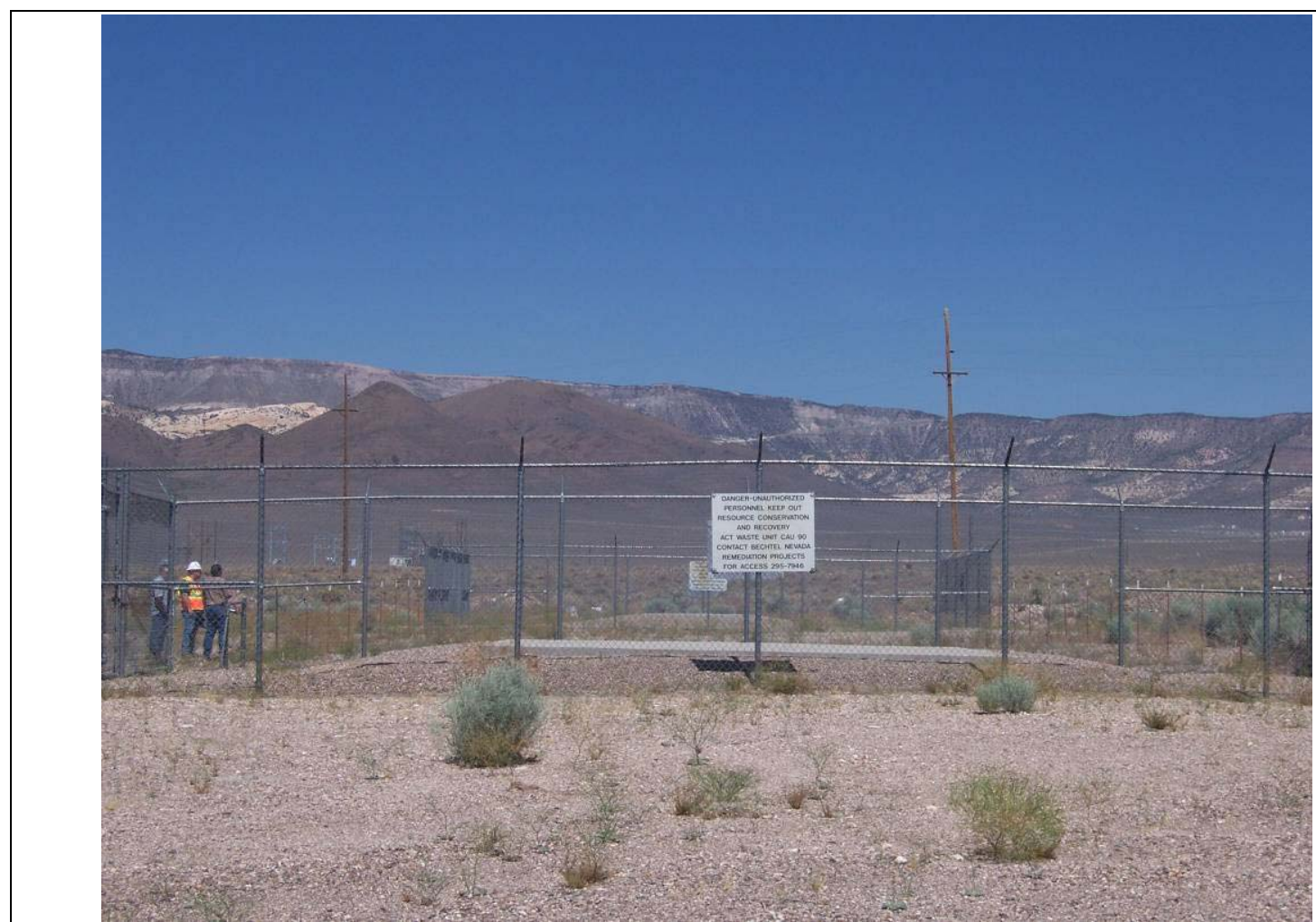

Photograph 11: View of east unit looking west, 6/17/2008

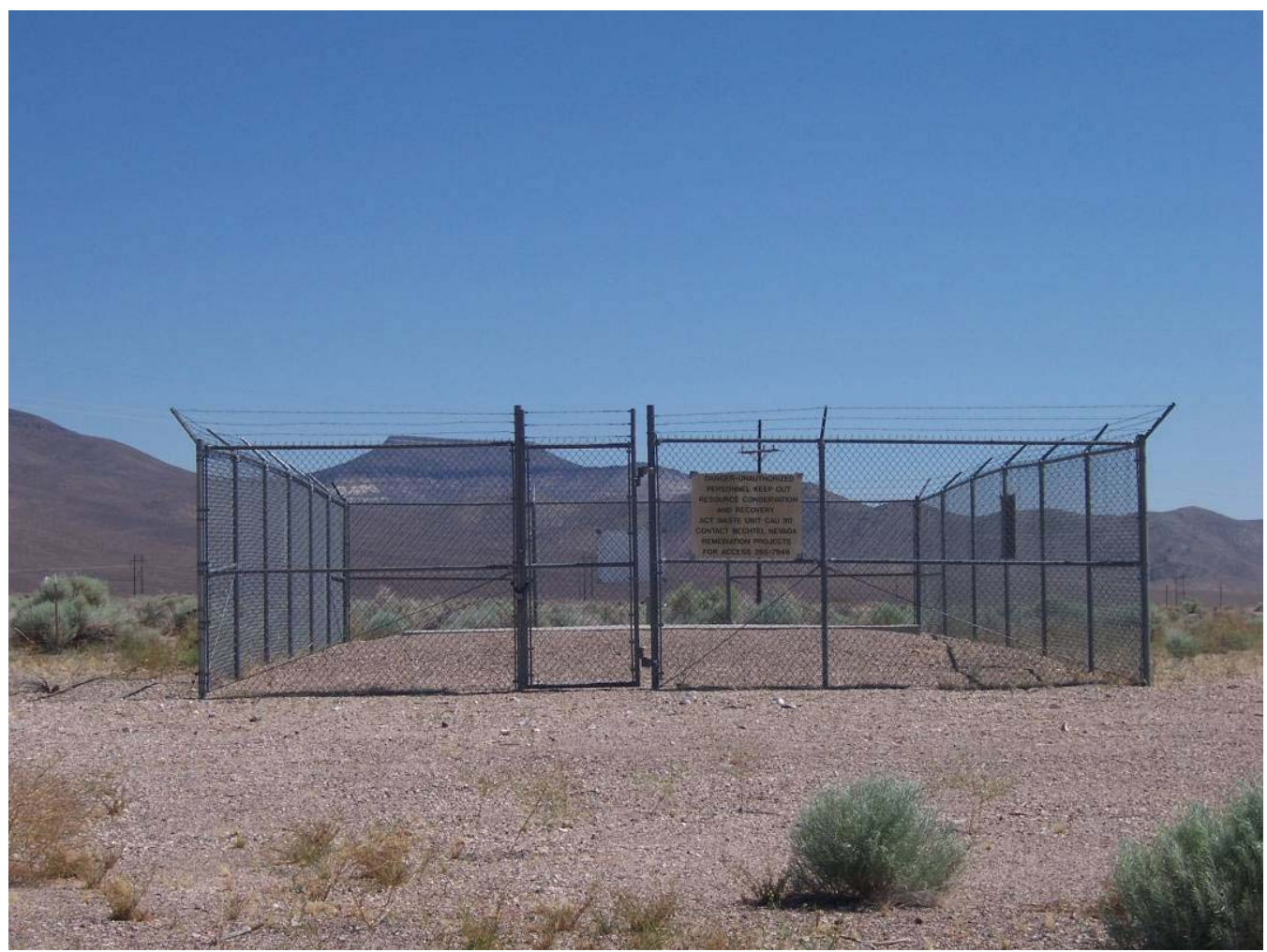

Photograph 12: View of east unit looking north, 6/17/2008 
CAU 90 Post-Closure Report

Revision: 0

Date: September 2008

\section{LIBRARY DISTRIBUTION LIST}


CAU 90 Post-Closure Report

Revision: 0

Date: September 2008

THIS PAGE INTENTIONALLY LEFT BLANK 


\section{LIBRARY DISTRIBUTION LIST}

U.S. Department of Energy

National Nuclear Security Administration

Nevada Site Office

Technical Library

P.O. Box 98518, M/S 505

Las Vegas, NV 89193-8518

U.S. Department of Energy

Office of Scientific and Technical Information

P.O. Box 62

Oak Ridge, TN 37831-0062

Southern Nevada Public Reading Facility

c/o Nuclear Testing Archive

P.O. Box 98521, M/S 400

Las Vegas, NV 89193-8521

Manager, Northern Nevada FFACO

Public Reading Facility

c/o Nevada State Library \& Archives

Carson City, NV 89701-4285
1 (Uncontrolled, electronic copy)

1 (Uncontrolled, electronic copy)

2 (Uncontrolled, electronic copies)

1 (Uncontrolled, electronic copy) 
CAU 90 Post-Closure Report

Revision: 0

Date: September 2008

THIS PAGE INTENTIONALLY LEFT BLANK 